\title{
EFFECT OF INFESTATIONWITH GLADIOLUS THRIPS, THRIPS SIMPLEX (MORISON) ON THEVASE LIFE PERIOD OF GLADIOLUS FLOWERS
}

\author{
EMAM, A. $\mathbf{S}^{\mathbf{1}}$. and HEBA METWALLY $\mathbf{H}^{\mathbf{2}}$. \\ 1. Plant Protection Institute, ARC, Dokki, Giza, Egypt \\ 2. Faculty of Science, Ain Shams University, Cairo, Egypt
}

(Manuscript received 27 July 2015)

\begin{abstract}

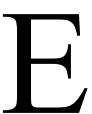
xperiments were carried out to study the effect of insect infestation by gladiolus thrips, Thrips simplex ( Morison ) on the vase life period of gladiolus flowers after picking under glasshouses condition and flowers contents specifically two elements (sugar and protein) which correlate with vase life period. Morevore effect of infestation with this insect on the interior tissues of the gladiolus flowers petals was also conducted. Experiments were done in El-Orman garden, Giza Governorate throughout season 2014. The vase life period of the infected gladiolus flowers with T.simplex ranged from between 3-5 days while the vase life period of non-infected flowers ranged between of 7-9 days. Results indicated that the total soluble sugar and total protein were significantly lowerin different flowercolures of gladiolus (yellow, red, pink and white) infested with gladiolus thrips, $T$. simplex compared with control. Also, results showed that there werechanges in protein banding patterns in petals of gladiolus flowers corresponded with infectionby $T$. simplex.
\end{abstract}

\section{INTRODUCTION}

Gladiolus became one of the important cut flowers in Egypt and around the world. It's used for decorations, and most of flowers bunches contains it. Most people all over the world love its colures. Gladiolus is derived from the native plants of south and central Africa as well as the Mediterranean region, Baydar (2004). Gladiolus family (Iridaceae ) is a valuable and economic flowering bulb used as a landscape plant in the home, gardens, as specimen for exhibition and used in decoration as a lovely and rich colored cut flower spike with relatively long vase life. Gladiolus is represented by 180 species and 10000 cultivars including almost all colors (Hogan, 1990). The gladiolus thrips, Thrips simplex (Morison) (Thysanoptera: Thripidae), which causes damage to leaves, flower stalks and buds bysucking. If flower buds are severely damaged, the flowers fail to open and dry out. The damage may also show asdiscolouration of open gladiolus flowers. The gladiolus thrips can overwinter on stored corms and on plantsgrowing in greenhouses if the temperature does not fall below $10^{\circ} \mathrm{C}$. This thermophile species may conclude itsdevelopment in two weeks and may form nine or more generations in a year. 
This work aims to study the effect of infestation byT. simplex on the vase life period of gladiolus flowers after picking under glasshouses condition correlated this withgladiolus flowercontents, specifically sugar and protein.

\section{MATERIALS AND METHODS}

\section{Experimental design:}

This study was conducted on Gladiolus plants grown in El-Orman Garden, Giza Governorate under glasshouse conditions duringsuccessive seasons 2014 .Two glasshouses with an area of $27 \times 45 \mathrm{~m}$ of each one,was divided into 9 plots $\left(3 \times 5 \mathrm{~m}^{2}\right)$, the first one of these glasshousescontainedtreated gladiolus and other one as control. The plots were arranged in randomized block with three replicates for treatment in the first glasshouse, and another three replicates as control in the second glasshouse. The $1^{\text {st }}$ glasshouse was artificially infected with $T$. simplex, the $2^{\text {nd }}$ one was left as control. The two glasshouses were in an area isolated from other trees in the garden. Also the first glasshouse was isolated from the second one.Gladiolus bulbs were planted in glasshouse conditions at the same time on September, (the planting time ofgladiolus bulbs). All agricultural operations of irrigation and fertilization and others are completely identical in the two glasshouses were donewithout application of any insecticide.

The artificially infestation was done with the $T$. simplex in the first glasshouse, with careful observation of the evolution of the $T$. simplexduring plant growth period and especially during the flowering stage with examining the second glasshouse (glasshouse free from and insects as control).

At the end of the first growing season, 100 flowers were collected from the $1^{\text {st }}$ glasshouse and 100 other flowersfrom the $2^{\text {nd }}$ glasshouse. In both of two glasshouses, all post-harvest treatment were identical, but conducted separately . Until the arrival of the flowers for the final stage, a stage put flowers in Wares glass (vase) where each group is divided into five containers respective 20 flower and in the presence of water only and without adding any other materials prolong or reduce the period of the existence or the life of flowers in glassware with taking into account the complete separation between the containers and controlcontainerswith daily monitoring of the status of flowers in both of the two glasshouses.

\section{Effect of T. simplexinfestation on components of Gladiolus flowers:}

The effect of infestation by T.simplexon Gladiolus flowers contents specifically two elements sugars and proteins, which correlated with the vase life period of flowers was studied. The samples contained three replicates (3 Gladiolus flowers 
plants) for each treatment and another three replicates as control. The gladiolus plants were highly infesting with thrips.

\section{Determination of protein banding pattern:}

\section{Total protein extraction:}

Total proteins were extracted from $0.5 \mathrm{~kg}$ fresh tissue. The tissues were ground in liquid nitrogen with a mortar and pestle. Then few mls of tris buffer extraction were added (1:2, tissue: buffer). The medium of extraction contained tris$\mathrm{HCL}$ buffer (0.1mM tris, pH 7.5, 4mM B-mercaptoethanol, 0.1mM EDTA-Na ${ }_{2}, 10 \mathrm{mM}$ $\mathrm{KCl}$ and $10 \mathrm{mM} \mathrm{MgCl}_{2}$ ). The crude homogenate was centrifuged at $10.000 \mathrm{xg}$ for $20 \mathrm{~min}$. The supernatant was used for gel analysis by SDS-polyacrylamide gel electrophoresis (SDS-PAGE) according to the method of Laemmli (1970).

\section{Loading on a gel:}

\section{Gel preparation:}

Sodium dodecyl sulphate polyacrylamide gel electrophoresis (SDS-PAGE) was performed using $12.5 \%$ acrylamide and $0.8 \%$ bis acrylamide running gel consisting of $0.375 \mathrm{M}$ Tris- $\mathrm{HCl}(\mathrm{pH} 8.8)$ and $0.1 \%$ SDS. Stacking gel $(10 \mathrm{~mm})$ was made using $4.5 \%$ acrylamide containing $0.8 \%$ bis-acrylamide in $0.125 \mathrm{M}$ Tris- $\mathrm{HCl}(\mathrm{pH} 6.8)$ and $0.1 \%$ SDS. The electrophoresis buffer contained $0.025 \mathrm{M} \mathrm{Tris-} \mathrm{HCl}, 0.19$ glycine and $0.1 \%$ SDS. The samples were homogenized in $0.12 \mathrm{M}$ Tris- $\mathrm{HCl}(\mathrm{pH} 6.8), 0.4 \mathrm{SDS}, 10$ B-mercaptoethanol, $0.02 \%$ bromophenolbule and $20 \%$ glycerol. The samples were then heated for $3 \mathrm{~min}$. in a boiling water bath before centrifugation. The gel was run under cooling at $90 \mathrm{v}$ for the first $15 \mathrm{~min}$, then $120 \mathrm{v}$ the next $0.5 \mathrm{hr}$ and finally $150 \mathrm{v}$ for the remaining $1.5 \mathrm{hr}$. Sheri, et al. (2000).

\section{Sample loading:}

A known volume of protein sample was applied to each well by micropipette. Control wells were loaded with standard protein marker.

\section{Electrophoresis conditions:}

The running buffer were poured into pre-cooled $\left(4^{\circ} \mathrm{C}\right)$ running tank. The running buffer was added in the upper tank just before running, so that the gel was completely covered. The electrodes were connected to power supply adjusted at 100 $v$ until the bromophenol blue dye entered the resolving gel, and then increased to $250 \mathrm{v}$ until the bromophenol blue dye reachs the bottom of the resolving gel.

\section{Gel Staining and distaining:}

After the completion of the run, gel was placed in staining solution consisting of $1 \mathrm{~g}$ of Coomassie Brilliant bule-R-250; $455 \mathrm{ml}$ methanol; $90 \mathrm{ml}$ glacial acetic acid and completed to $1 \mathrm{~L}$ with deionized distilled water. The gel was destained with $200 \mathrm{ml}$ destaining solution $(100 \mathrm{ml}$ glacial acetic acid, $400 \mathrm{ml}$ methanol and completed to $1 \mathrm{~L}$ by 
distilled water) and agitated gently on shaker. The destaining solution was changed several times until the gel background was clear.

\section{Gel analysis:}

Gels were photographed using a Bio-Rad gel documentation system. Data analysis was obtained by Bio-Rad Quantity one Software version 4.0.3.

\section{Statistical analysis:}

In the experiments, the effect of the insect infestation by the gladiolus thrips, $T$. simplexon total soluble sugar and total protein of the gladiolus flowers were subjected to analysis of variance (ANOVA) and the means were compared by L.S.D. test at 0.05 level, using SAS program (SAS Institute, 1988). The sugar and protein were analyzed by High Pressure Liquid Chromatograph (HPLC).

\section{RESULTS AND DISCUSSION}

\section{Effect of insect infestation with gladiolus thrips, $T$. simplex on the vase life period of gladiolus flowers :}

The gladiolus thrips, T. simplexcan infest gladiolus plants grown with glasshouse and interfere with the plant processes under investigation or with green plant health. Therefore, a major effort in glasshouses should be directed toward avoiding infestation of plants with thrips.

Results in Table (1) indicated that the mean lifetime (vase life period) of the infected gladiolus flowers with the $T$. simplex ranged between 3-5 days, while the mean of vase life period of gladiolus flowers non-infected with insects (control) ranged between 7-9 days. T. simplexsucking the flower sap andfeeding on juices, leading to dryness and reduction of life time ( vase life period ) of flowers after cutting because of collapse of plant cells, deformed plant growth and flower deformation. This means that gladiolus flowers should be preserved free of the infestation with the gladiolus thrips, T. simplex to elongate the life time (vase life) of flowers.

Table 1. Effect of infestation with gladiolus thrips, $T$. simplex on the vase life period of gladiolus flowers after picking.

\begin{tabular}{|c|c|}
\hline \multicolumn{2}{|c|}{ Life time (Vase life) period in days } \\
\hline T. simplex & Control \\
\hline 3 & 7 \\
\hline 4 & 8 \\
\hline 5 & 9 \\
\hline
\end{tabular}




\section{Effect of insect infestation with $T$. simplexon the gladiolus flowers components:}

Data in Table (2) show the total soluble sugar content in different gladiolus flowers colours after infestation with gladiolus thrips, $T$. simplexcompared with control. They were $30.55,25.11,18.47$ and $9.57 \mathrm{mg} / \mathrm{g}$ in yellow, red, pink and white flowers colours after infestation with thrips, respectively, while these values were $41.25,33.98,24.14$ and $14.33 \mathrm{mg} / \mathrm{g}$ in control, respectively.

Table 2. Determination of total soluble sugar $(\mathrm{mg} / \mathrm{g})$ in different colors of gladiolus flowers after infestation with gladiolus thrips, T. simplex.

\begin{tabular}{|c|c|c|}
\hline \multirow{2}{*}{ Colour } & \multicolumn{2}{|c|}{ Determination of soluble sugar $(\mathrm{mg} / \mathrm{g})$} \\
\cline { 2 - 3 } & T. simplex & Control \\
\hline Yellow & $30.55^{\mathrm{a}}$ & $41.25^{\mathrm{a}}$ \\
\hline Red & $25.11^{\mathrm{b}}$ & $33.98^{\mathrm{b}}$ \\
\hline Pink & $18.47^{\mathrm{c}}$ & $24.14^{\mathrm{c}}$ \\
\hline White & $9.57^{\mathrm{d}}$ & $14.33^{\mathrm{d}}$ \\
\hline F & 833.03 & 65.53 \\
\hline LSD & 1.0213 & 4.7232 \\
\hline
\end{tabular}

Means within columns bearing different subscripts are significantly different $\quad(P<0.05)$

Generally, the infestation with thrips reduced total soluble sugar. Also, the yellow color flower contained more total sugar than the other colours (red, pink and white).

Statistical analysis in (Table 2) show high significant differences between the total soluble sugar in different flowercolors, which either infested with thrips or control $(F=833.03$ and $65.53 \&$ L.S.D. $0.05=1.0213$ and 4.7232$)$, respectively.

The obtained results are in agreement who those obtained by Ashraf (2009) in Egypt which studied the effect of Macrosiphum rosae (aphid) and Frankliniella occidentalis (thrips) on the interior components of rose flowers, Ellsworth, et al. (1993) who reported that Pear thrips reduced whole-tree leaf area and reduced leaf size although leaf chlorophyll content and leaf mass per unit area were apparently not affected. pearthrips feeding has no effect on leafwater use efficiency, but it may reduce leaf net $\mathrm{CO} 2$ assimilation rate, as a result of direct tissue damage or through reduced stomatal conductance (gs). So, the infected plants have reduced amount of sugars may be due to the reduction of green area of leaves which caused by the insect, and therefore reduce the efficiency of photosynthesis and so reduce the amount of total sugars. 
Jaskiewicz (2006) in Poland studied the effect of the aphids M. rosae feeding on the flowering of roses and reported that aphid $M$. rosae when found in greater numbers caused deformation of the leaf blades, shorting of shoots and petioles, as well as deformation of the flowers. Also Sutterlin (2005) in Netherlands studied the effect of $F$. occidentalis on rose plants and reported that flower damage caused by $F$. on the season and number of thrips on the flower and conducted a study to determine the relationship among silver damageon leaves flower damage. Sauer (1997) in Germany reported that petal damage could not always be attributed to thrips infestation (number of thrips) only but also attributed to the time of the infestation. Total infestation percentages depending on the average colonization/week. Thomson (2008) studied the changes in the internal components of rose plants such as protein, sugar and vitamins, which infested with some insects and decided that the most effective were Macrosiphum rosae and Frankliniell atritici.

Data in Table (3) show the total protein content in different gladiolus flowerscolors after infestation with gladiolus thrips, $T$. simplexcompared with control. They were 42.8, 34.8, 23.4 and $19.9 \mathrm{mg} / \mathrm{g}$ in yellow, red, pink and white gladiolus colors after infestation with thrips, respectively. while they reached 48.7, 39.5, 29.4 and $21.7 \mathrm{mg} / \mathrm{g}$ in yellow, red, pink and white gladiolus flowers colors in control, respectively. Generally, the infestation with thrip reduced total protein. Also, the yellow color rose contained more total protein than the other colors (red, pink and white).

Statistical analysis in (Table 3) show high significant differences between the total protein in different gladiolus colours, which infested with thrips compared with control $(F=236.90$ and 1197.32 \& L.S.D. $0.05=2.2298$ and 1.1099), respectively. The obtained results are in agreement who those obtained by Ashraf (2009) in Egypt who studied the effect of $M$. rosae and $F$. occidentalis on the interior components of rose flowers. He reported that the total protein in the rose petals reduced as result to the infestation by thrips F. occidentalis. Becker and Apel (1992) reported that the decrease in total protein may be due to the decrease in carbohydrate content which act as a carbon source in protein synthesis. Voloshenko and Khachumov (2008) reported that the infestation by Macrosiphum rosae and Frankliniell atritici were changed in the protein pattern in the rose petals. While, Tremewan (2008) studied the changes, which happened in protein pattern in the rose petals, which infested by were Macrosiphum rosae and Frankliniell atritici. 
Table 3. Determination of total protein $(\mathrm{mg} / \mathrm{g})$ in different colors of gladiolus flowers after infestation with gladiolus thrips, $T$. simplex

\begin{tabular}{|c|c|c|}
\hline \multirow{2}{*}{ Colour } & \multicolumn{2}{|c|}{ Determination of total protein per $(\mathrm{mg} / \mathrm{g})$} \\
\cline { 2 - 3 } & T. simplex & Control \\
\hline \multirow{2}{*}{ Yellow } & $42.8^{\mathrm{a}}$ & $48.7^{\mathrm{a}}$ \\
\hline Red & $34.8^{\mathrm{b}}$ & $39.5^{\mathrm{b}}$ \\
\hline Pink & $23.4^{\mathrm{c}}$ & $29.4^{\mathrm{c}}$ \\
\hline White & $19.9^{\mathrm{d}}$ & $21.7^{\mathrm{d}}$ \\
\hline F & 236.90 & 1197.32 \\
\hline LSD & 2.2298 & 1.1099 \\
\hline
\end{tabular}

Means within columns bearing different subscripts are significantly different $\quad(P<0.05)$

\section{Change in protein pattern:}

Table (4) and Fig. (1) show the changes in protein banding patterns of petals of gladiolus flowers plants in response to infected by gladiolus thrips, T. simplex.

Table (4) indicate the occurrence of twelve common protein bands appeared in the petals of control and in petals response to the applied infestation by thrips (M.wt: 115.0, 89.0, 77.0, 65.0, 51.0, 33.0, 31.0, 25.0, 22.0, 25.4, 16.1, and 12.7 $\mathrm{kDa})$.

Two different polypeptides with molecular weights (199.0 and $31.9 \mathrm{kDa}$ ) were not detected as common bands in petals in response to infestationby Thrips and in the control. Five different polypeptides with molecular weights (30.7, 19.9, 14.8, 11.14 and $11.2 \mathrm{kDa}$ ) were detected as common bands in control and not detected in the infested petals. Lastly. the previous table revealed that; while the infestation by Thrips resulted in the appearance of one unique protein bands (Mwt: $44 \mathrm{kDa}$ ) in the infested petals which not detected in the control.. The obtained results are in agreement with those obtained with Becker and Apel (1992) who reported that the unique protein band which appear inresponse to infestation by thrips may be a defense protein which play an important role in defense mechanism of plant against the insects, and reported too that the protein with m.wt 40 belongs to pathogen- related protein Voloshenko and Khachumov (2008) reported that the infestation by $M$.rosaeand F.triticichanged the protein pattern in the rose petals. 
Table 4. Change Induced by infestation with gladiolusthrips, T. simplexin the Protein Banding Pattern (amino acids) of gladiolus flowers.

\begin{tabular}{|c|c|c|c|c|}
\hline No of band & M.wt. (kDa) & Marker (M) & Control & Thrips \\
\hline 1 & 199.0 & Glycen & - & - \\
\hline 2 & 115.0 & Alanen & + & + \\
\hline 3 & 89.0 & Valen & + & + \\
\hline 4 & 77.0 & Liocen & + & + \\
\hline 5 & 65.0 & Isoliocen & + & + \\
\hline 6 & 51.0 & Brolen & + & + \\
\hline 7 & 44.0 & Venilalanen & - & + \\
\hline 8 & 31.9 & Treptovan & - & - \\
\hline 9 & 33.0 & Methionen & + & + \\
\hline 10 & 31.0 & Aspartek acid & + & + \\
\hline 11 & 30.7 & Glotamic acid & + & - \\
\hline 12 & 25.0 & Laycen & + & + \\
\hline 13 & 22.0 & Argnen & + & + \\
\hline 14 & 25.4 & Hesteden & + & + \\
\hline 15 & 19.9 & Seren & + & - \\
\hline 16 & 16.1 & Therionen & + & + \\
\hline 17 & 14.8 & Tairocen & + & - \\
\hline 18 & 12.7 & Sestayn & + & + \\
\hline 19 & 11.14 & Asparagen & + & - \\
\hline 20 & 11.2 & Glotamen & + & - \\
\hline $\begin{array}{c}\text { Total No of } \\
\text { bands }\end{array}$ & - & 20 & 17 & 13 \\
\hline
\end{tabular}

M.wt. : Molecular weights

kDa : Kilo Dalton 


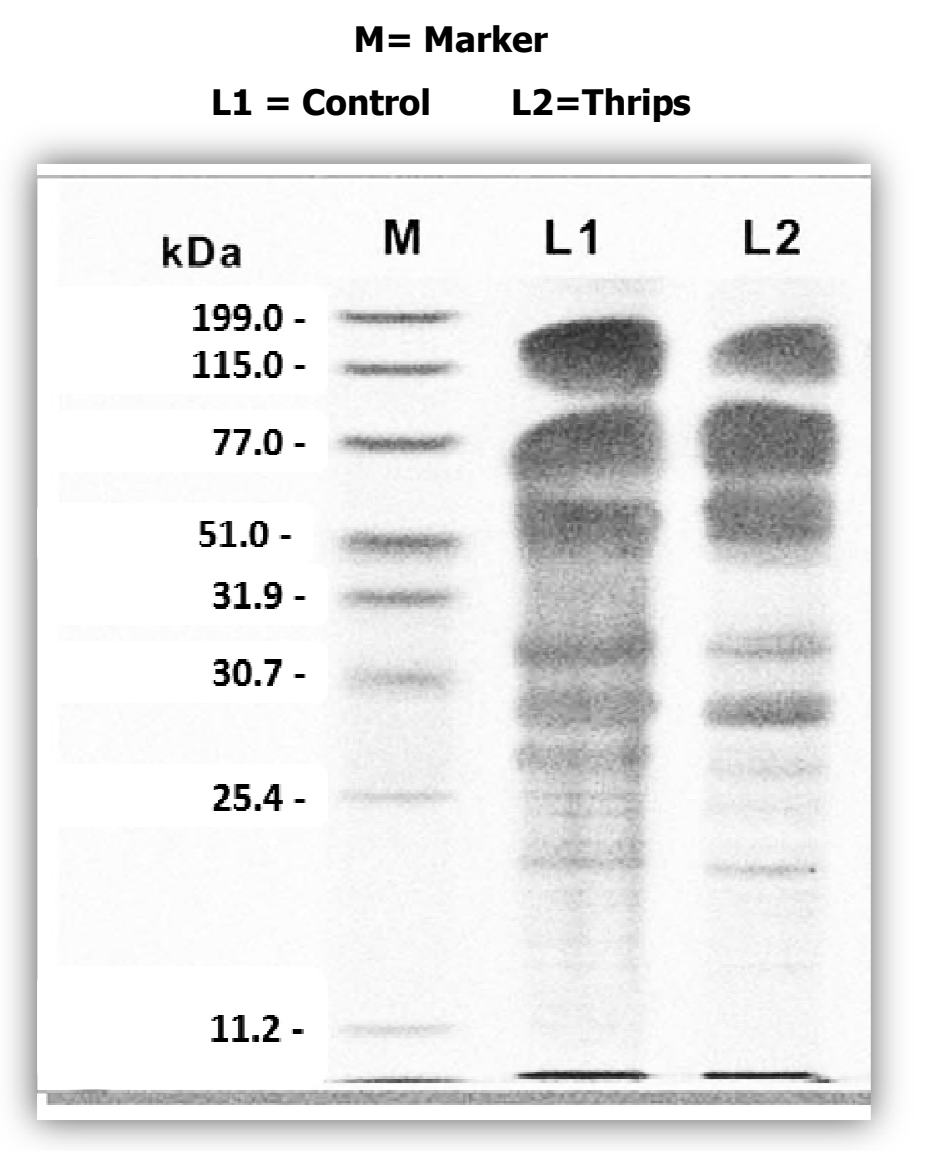

Fig. 1. Change in protein banding pattern (amino acids) of gladiolus flowers petals in response to gladiolus thrips, T.simplex infestation.

\section{REFERENCES}

1. Ashraf, S. E. 2009. Effect of insect infestation on some rose plants. Ph.D. Thesis, Fac. Agric.,Al-Azhar Univ.,Cairo, Egypt.

2. Baydar, H. 2004. The cultivation of the oil producing rose and the rose oil industry in Turkey Turktarm, (160): 54-57.

3. Becker, W. and K. Apel. 1992. Isolation and characterization of cDNA clone encoding a novel jasmonate - induced protein of barley (Hordeum vulgare L. ). Plant Mol. Biol. 19: 1065-1067.

4. Ellsworth, D. S. , M. T. Tyree, B. L. Parker and M. Skinner. 1993. Photosynthesis and water-use efficiency of sugar maple (Acer saccharum) in relation to pear thrips defoliation. Oxford J. Sci. \& Mathematics Tree Physiol. Volume 14, Issue 6 Pp.619-632.

5. Hogan, L. 1990. Bulbs for all seasons. Sunset western Garden Book, Menlo Park, CA: Lane Publishing, California, pp: 185-198. 
6. Jaskiewicz, B. 2006. The effect of the feeding of Macrosiphumrosaeformis and Chaetosiphontetrarhodum (Walk.) on the flowering of roses. Acta-Agrobotanica ; 59 (1) : 515-520.

7. Laemmli, U.K. 1970. Cleavage of structural proteins during the assembly of the head of bacteriophage T4.Nature. 1970 Aug 15;227(5259):680-5.

8. Peng, Z. and P. W. Miles. 1991. Oxidases in the gut of an aphid Macrosiphumrosaeformis and their relation to dietaryphenolics. J. Insect Physiol, 37 (10): 779 - 787.

9. SAS Institute. 1988. SAS/STAT User`s Guide, Ver. 6.03. SAS Institute Inc., Cary, North Carolina.

10. Sauer, A. 1997. Population dynamics of Thysanoptera and infestation differences in roses in the greenhouse. MitteilungenderDeutschenGesellschaft fur Allgemeine und Angew. Entomol., 11 (1/6): 337-340 .

11. Shama, A. and J. K. Johri. 2004. Insect pests of some economically important ornamental plants. J. Entomol. Res., 28 ( 2 ) : 137 - 145.

12. Sheri, L. H. ; E. S. Nicolas ; T. K. Michae and B. G. Joanna. 2000. Comparison of protein expressed by Pseudomonas aeruginosa strains representing initial and chronic isolates from a cystic fibrosis patient: an analysis by 2-D gel electrophoresis and capillary column liquid chromatography tandem mass spectrometry. Microbiol. 146: 2495- 2508.

13. Sutterlin , S. 2005. The art of making things simple: insect resistance tests and their practical implementation. Bulletin - OILB / SROP ; 28 (10): 61- 65. 
THRIPS SIMPLEX (MORISON) آثز الاصابة الحشرية بحشرة تربس الجلاديولس على طول فترة حياة أزهار الجلاديولس بعد القطف

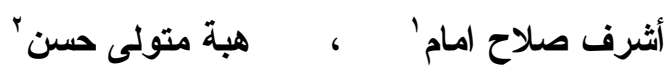

$$
\begin{aligned}
& \text { I . معهُ بحوث وقاية النباتات - مركز البحوث الزراعية- الدقي - الجبزة - مصر } \\
& \text { r . كلية العلوم -جامعة عبن شمس- القاهرة - مصر }
\end{aligned}
$$

تعتبر أزهار الجلاديولسمن أهم زهور القطف على الإطلاق والتى لا يكاد تخلو منه

$$
\text { بوكيهات الزهور على اختلاف مستوياتها وذلك لجمال أنكالها و تميز ألوانها. }
$$

تم إجر اء التجارب بغرض دراسة تأثثر الإصابة بحشرة تربس الجلاديولس علي طول فترة

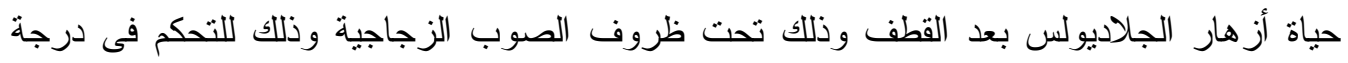
الاصابة بالحشرة محل الدراسة. وكذلك دراسة تأثير الإصابة بالحشرة ذاتها علي محتوى أزهار الجلاديولس من عنصرى السكريات و البروتين ، هذان العنصران المرتبطان ارتباطا وثثيا بفترة

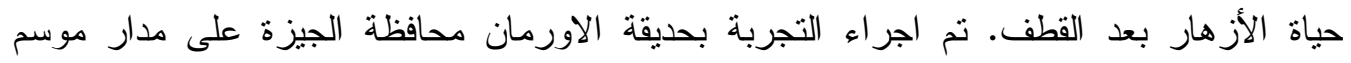

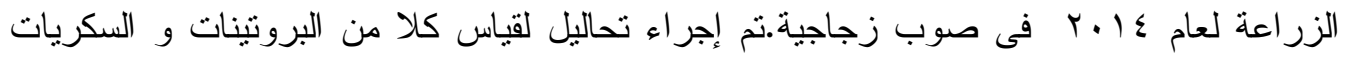

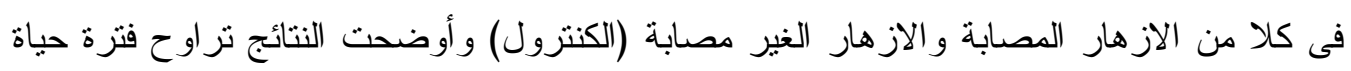
الاز هار المصابة بحشر ات نربس الجلاديولس من بـ هـ هـ أيام فى حين نز اوحت فترة حياة الازهار

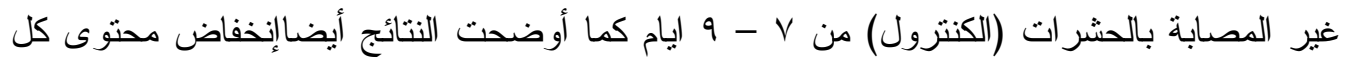
من البروتنيات و السكريات في أزهار الجلاديولس المصابة بالحشرة محل الدراسة مقارنة بالكنترول.

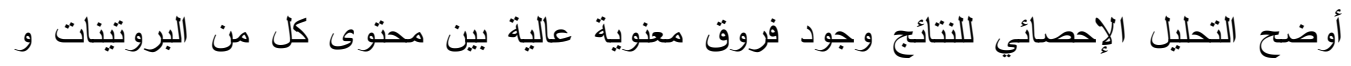
السكريات للألوان المختلفة لأزهار الجلاديولس بعد الإصابة بحشرة تزبس الجلاديولس. 